\title{
3. フリーラジカルと抗加齢医学
}

吉川 敏一1) 市川寛 ${ }^{2}$

Key words : 活性酸素, フリーラジカル, 抗加齢医学, 予防医学

（日老医誌 $2008 ； 45 ： 149-151 ）$

\section{はじめに}

高齢化社会の到来とともに，わが国でも健康に関する 関心が高まってきている。一般的には, 疾病の予防や健 康維持にはバランスのとれた食生活や適度な運動は非常 に有用とされるが，高齢者を対象とした場合，老化に伴 う消化管機能の低下や運動不足などにより，単なる生活 習慣の改善のみでは補えない部分があるとされる.

高齢者に対する医療・保健の問題を考えた時, 目標と

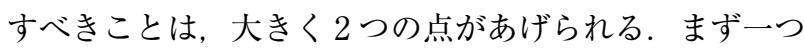
は，疾病を治療することだけでなく，疾病を予防し，健 康な余命を延長させることにある，いま一つは，さまざ まな健康レベルにある高齢者の「健康」を保持し, サク セスフルエイジングを達成させるために実践することに ある。これら 2 つ目標を達成させるには, 地域におけ る高齢者の身体や精神に対する包括的な健康評価が必要 であり，医師や保健師，栄養士のみならず，広く健康と 保健に係わる専門家の協力が必要となってくる.

近年, 抗加齢, 抗老化あるいはアンチエイジングとい う言葉がよく聞かれるようになっている。 アンチエイジ ング（抗加齢）が注目されている理由は，いうまでもな く高齢化社会を意識してのことであり，単に寿命を延長 するだけでは意味がなく，生活の質を維持し，生きがい のある人生を送ることこそ重要であるとの認識が出てき たことが挙げられる。この抗加齢医学とは, 従来の医療 が対象にしていた「病気の治療」から,「健康な人のさら なる健康」を指導するプラスの医療で，元気に長寿を享 受することを目指す理論的・実践的科学ともいえる.

Anti-aging medicine and reactive oxygen species

1) Toshikazu Yoshikawa：京都府立医科大学大学院医 学研究科消化器内科学

2) Hiroshi Ichikawa：京都府立大学人間環境学部食保 健学科
本稿では, 活性酸素・フリーラジカルの基礎, 老化と の関わり，および，抗加齢医学における抗酸化療法の有 効性について解説する.

\section{活性酸素・フリーラジカルと老化}

「老化」と「加齢」は混同されやすい概念であり，通

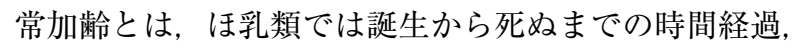

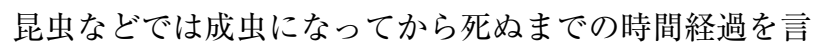
う.すなわち，多くの動物では「加齢」の間に「老化」 が進むわけである.

老化の成因に関して，これまで数多くの説が出されて いるが，現在考えられている老化のメカニズムは，大き く分けて,「老化プログラム仮説」と「誤り蓄積仮説」の

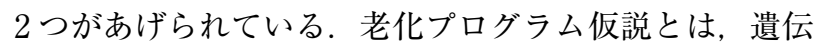
子 DNA 内に老化についてのプログラムがあらかじめ組 み込まれているとするものである。 また，誤り蓄積仮説 とは, 遺伝子や生体を構成している蛋白質などの構造に 少しずつエラーが蓄積されて, それが生体機能を傷害す ることにより，老化や病気を引き起こし，結果として寿 命を縮めるという考え方である．老化に対する考え方の 違いから, これら 2 つ説以外に, 体細胞突然変異説, 代謝産物蓄積説, 架橋結合説, すり切れ (摩耗) 説, 免 疫異常説, ストレス説, 生活代謝率説, 生物時計説, 神 経内分泌説などが提唱されているが，これら老化仮説に 共通して深く関与しているものとして注目されているも のが, 活性酸素・フリーラジカルである.

通常, 原子は原子核を中心として, 各電子軌道に 2 個 の電子が対になって存在するが, 稀に対になっていない 電子があり，これを不対電子とよんでいる。この不対電 子を持つ分子や原子をフリーラジカルといい, フリーラ ジカルは一般的に不安定で反応性が大きい.ところで, 酸素分子は，その生体内に扔ける代謝過程で 4 電子還元 を受け，その還元の過程，あるいはエネルギー付与によ 
$45: 150$

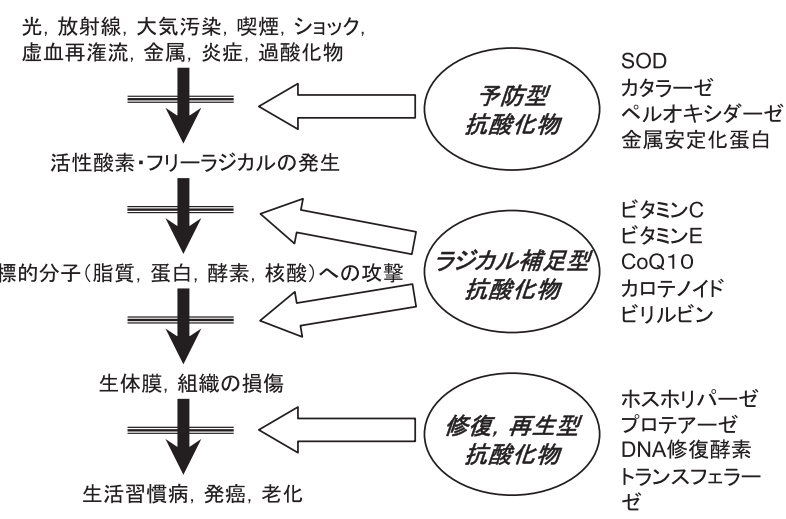

図 1 生体内で作用する抗酸化物質

る電子の励起，遷移金属との結合により，反応性が高ま る.このようにして生じた酸素分子による活性の高い酸 素種を総称して活性酸素とよんでおり，スーパーオキシ ドラジカル, 過酸化水素, ヒドロキシルラジカル, 一重 項酸素の 4 種類が活性酸素種として認められている.

生体内においては, ミトコンドリア電子伝達系あるい はミクロソーム電子伝達系内のある種の酵素, オキシ ダーゼ系酵素, 鉄含有蛋白質などが活性酸素・フリーラ ジカルの生成系に関与している。 また，上記以外に，ウ イルスや細菌が体内に侵入した場合，これを除去する目 的で免疫担当細胞であるマクロファージや好中球が産生 したり，化学物質などの解毒の際に肝臓において産生さ れ，さらには，激しい運動をした場合にもその産生増強 が確認されている。

活性酸素・フリーラジカルは生体内で生成されるだけ ではなく，外部環境にも多く存在する。その生成環境因 子としては，大気污染物質，放射線，ある種の薬剤，紫 外線，たばこなどが知られており，こうした環境因子に 接することにより活性酸素・フリーラジカルを生体内に 取り込むことになる.

1956 年に D. Harman が活性酸素と老化の関係を報告 して以来，老化と活性酸素・フリーラジカルに関する研 究は急速に進み，現在，老化促進を抑制するには，生体 内での活性酸素・フリーラジカルの生成, 消去, 修復の バランスが重要であるという結論に達している。すなわ ち,「抗酸化防御機構」や「酸化傷害修復系」により防御 できない加齢に伴う「酸化ストレス」の蓄積が，老化の 原因であると結論づけられている（図 1)。酸素を利用 して生きている動物の寿命を規定する因子が活性酸素で あり, 抗加齢という重要な課題は, 実はこの活性酸素・ フリーラジカルによる細胞, 遺伝子レベルでの傷害を防
ぐこと，すなわち抗酸化能を持ち合わせるかどうかにあ ると考えられる。

\section{活性酸素・フリーラジカルの排除による 老化遅延}

現在，老化遅延，寿命延長の可能性のある方法として は, 唯一カロリー制限による方法であるといわれている. ラットやマウスでは, カロリー制限により大幅に寿命が 延長するだけでなく，老化関連病態の発症が遅れ，加齢 に伴う各種生理機能の老化を抑えることが認められてい るが，このことは，カロリー制限が動物種に共通する老 化の基本的メカニズムに影響していることを示唆させ る。また，適度な運動は，呼吸・循環機能を改善し，筋 力を高め, 肥満, 高血圧, 糖尿病に代表される生活習慣 病を予防し，心身の老化現象を遅らせるとする多くの研 究報告がある。

さらに, 活性酸素・フリーラジカルを消去する能力が 大きいほど長寿であるならば，抗酸化物質を多く摂取す れば老化を遅延させることができるはずであり，ビタミ ン $\mathrm{E}, \mathrm{C}, \mathrm{A}$ などの抗酸化物質が注目されている。 たと えば，動物を使った報告ではあるが，ワムシや線虫など の下等動物を用いた実験では, ビタミン $\mathrm{E} の$ 投与によ り最大寿命の延長が観察されており，哺乳動物ではリポ フスチンの蓄積やアミロイド沈着などが，ビタミン $\mathrm{E}$ で抑制されている，また，ビタミンCでは，マウスへ の連続投与により平均寿命がのびることがよく知られて いる.

ところで，現在抗酸化物質が抗加齢を目的に摂取され ている根拠は，抗酸化物質を豊富に含む野菜や果物を積 極的に食べる人ではある種の癌の発生率が低いことや， 日本において野菜を多く食べる人で脳卒中の発症率が低 かったなどの疫学的な研究から, 抗酸化物質が癌や動脈 硬化性疾患を予防できるのではないかと考えられたため である.ビタミンCについては虚血性心疾患の発症率 を下げたとのメタアナリシスの報告はあるが，しかしな がら, 現在, ビタミン $\mathrm{E} や \beta$ カテンなどの長期投与 に対する否定的なメタアナリシスの報告も多く見受けら れ，抗加齢に対する抗酸化物質の是非については今後さ らに検討されるべきものがあることを付け加えておく.

\section{おわりに}

抗加齢医学の目的とするところはいずれも健康長寿で あり，その目標を達成させるための抗加齢医療の実践に は，具体的には医学的根拠に基づいた薬物・栄養療法に 加え，さまざまな治療法を効率的に統合した「代替医療」 
$45: 151$

を導入していくことが要求される.

活性酸素・フリーラジカルによる酸化ストレスから老 化を考えた場合，さまざまな抗酸化物質を体内に取り込 み，活性酸素に打ち勝つ身体を形成することが，老化現 象を予防・改善させる一つの手段と考えられ，この抗酸 化療法は抗加齢の手法として今後も注目される分野であ る.
老化研究の発展により, 老化は遺伝的影響よりも, 環 境的影響の方が大であるということが明らかになってき ていることを考えると, 不老不死は無理としても, 抗加 齢医学の介入と, 個人の努力により, 老化を遅らせ, 健 康寿命を少しでも延長させることは可能であると考え る. 